\title{
Land Use and Climatic Conditions Control the Soil Organic Carbon's Distribution in Qufu and Laixi, North China Plain
}

\author{
Huafeng Liu ${ }^{1,2}$, Huanfang Huang,4* \\ ${ }^{1}$ Shandong Institute of Geological Survey, Jinan 250013, China \\ ${ }^{2}$ Shandong Engineering Research Center of Land Quality Geochemistry and Pollution Prevention, Jinan 250014, China \\ ${ }^{3}$ State Key Laboratory of Organic Geochemistry, Guangzhou Institute of Geochemistry, \\ Chinese Academy of Sciences, Guangzhou 510640, China \\ ${ }^{4}$ School of Environmental Studies, China University of Geosciences, Wuhan 430078, China
}

Received: 6 August 2020

Accepted: 31 October 2020

\begin{abstract}
Understanding the factors controlling the distribution of soil organic carbon (SOC) is crucial to estimate SOC stocks and explore the optimal soil management for carbon sequestration and migrating climate change. Herein, we quantitively evaluated the influences of land use (farmland and wasteland), soil properties ( $\mathrm{pH}$, eight heavy metals, and seven minerals), and climatic conditions (temperature and precipitation) on the spatiotemporal variation of SOC in surface soils $(0-20 \mathrm{~cm})$ and soil columns $(180 \mathrm{~cm})$ in Qufu and Laixi, North China Plain. SOC concentrations in surface soils and soil columns were $1.84-27.4$ and $1.82-9.33 \mathrm{~g} / \mathrm{kg}$, respectively. With ca. $64 \%$ of SOC stored in $20-180 \mathrm{~cm}$ layers and the dramatic increase rate of $>70 \%$ for SOC in soil columns, SOC in subsoil showed its more considerable significance than that in the surface soil. Land use and climatic conditions contributed avg. 45.6 and $41.5 \%$, respectively, to SOC in surface soils and 54.3 and $26.6 \%$, respectively, in soil columns. Our results suggest the dominant influences of land use and climatic conditions on the SOC distribution and reemphasize the considerable importance of SOC in subsoil because of the high storage and storage potential of SOC in subsoil.
\end{abstract}

Keywords: soil organic carbon, land use, $\mathrm{pH}$, heavy metals, climatic condition

\section{Introduction}

Studies on the spatial-temporal distribution of soil organic carbon (SOC) and the controlling factors in a specific region has always been essential for

*e-mail: hhuanfang@sina.com, huanghuanfang@gig.ac.cn understanding the SOC storage. Such studies are specially enhanced with the recent concerns on the increasing $\mathrm{CO}_{2}$ levels in the atmosphere and consequent global warming. The amount of SOC storage depends on the input-output balance of organic matter and is primarily determined by the combined interaction of land use [1], soil conditions [2], and climate factors [3]. The main controlling factor may be different in various 
regions due to different environmental conditions [4], necessitating the evaluation of the dominant influence factor in a specific area [5].

Land use is believed to be the most dynamic factor for SOC changes reported in numerous studies [6, 7]. The conversion of forest and grassland to cropland would lead to a distinct decrease of SOC due to the enhancement of soil erosion [8], declined carbon input [9], reduced stabilization of organic matter, and exacerbated carbon decomposition [9]. For example, the average SOC concertation in Northeast China had dropped by nearly $45 \%$ in about 300 years of farming [10]. The loss of SOC can be reserved by returning farmland to forest and grassland [11] and can also be reserved by land management, such as ceasing cultivation and straw-return treatment, by increasing the carbon input, enhancing the soil stabilization, and reducing the exposure of SOC [3, 12]. The critical influences of soil properties and climatic conditions were also frequently reported. The specific influencing factors include, but are not limited to, $\mathrm{pH}$, heavy metals, minerals, temperature, and precipitation. Generally, $\mathrm{SOC}$ tends to increase with decreasing soil $\mathrm{pH}$. The low $\mathrm{pH}$ depresses the decomposition of organic matter by reducing microbial activity and increasing the protection of minerals [13]. Heavy metal can protect the SOC from degradation by alerting the microflora and decreasing the microorganisms' activities $[14,15]$. The interactions between soil minerals and SOC at different levels protect organic components from further degradation [16], which suggested the critical role of minerals in the long-term storage and stability of SOC [2]. Temperature and precipitation affect SOC stock at various scales by affecting carbon input and SOC decomposition [3]. Under normal circumstances, SOC increases with high precipitation and low temperature (i.e., under cold, humid conditions) [10].

Most experimental studies discussed above investigated the impact of individual factors on the changes in SOC stock. However, the SOC in the natural environment is the combined result of complex factors. Besides, most current studies employed shallow sampling to investigate the SOC variation under different treatments while generally disregarding the whole soil profile, which may introduce bias [17]. Despite the low carbon concentration, most subsoil horizons contribute to more than half of the total soil carbon stocks $[18,19]$. Therefore, it is essential to include factors as many as possible with the consideration of the whole soil profile for an accurate assessment of SOC storage and storage potential, and for the exploration of the optimal land use management in a specific region.

In this study, we hypothesize that (1) SOC is controlled by several factors, rather than just one; (2) SOC in soil column is of greater significance with particular reference to the SOC storage assessment and land management for increasing SOC sequestration. To verify our hypotheses, we collected surface soils and soil columns in farmland and wasteland from
2010 to 2012 to (1) investigate the spatial-temporal distributions of SOC in surface soils and soil columns; and (2) quantitively examine the influences of land use (farmland and wasteland), soil properties (including $\mathrm{pH}$, eight heavy metals and seven minerals) and climatic factors (temperature and precipitation) on the SOC distributions.

\section{Materials and Methods}

\section{Study Areas}

The North China Plain includes Beijing, Tianjin, Hebei, Shandong, Henan, Anhui, and Jiangsu Provinces (total area: ca. $300,000 \mathrm{~km}^{2}$ ) and has a massive population of ca. 339 million. It is one of the most critical breadbaskets in China. Intensive farming in North China has led to severe consequences, including the declined groundwater table [20] and environmental pollution because of the straw burning [21]. Strawreturn is an effective treatment for agricultural development and ecological protection and widely applied in the farmland in the North China Plain. Our study areas - Qufu $\left(35.4545^{\circ} \mathrm{N}, 117.0239^{\circ} \mathrm{E}, 90 \mathrm{~m}\right.$ a.s.1.) and Laixi $\left(36.8760^{\circ} \mathrm{N}, 120.5024^{\circ} \mathrm{E}, 75 \mathrm{~m}\right.$ a.s.l.) are in the west and east of Shandong Province, North China Plain (Fig. 1a) and can represent the general SOC conditions in Shangdong Province. Both Qufu and Laixi belong to the semi-arid region, with the main landform types of hills and plains. The temperate continental monsoon climate prevails in both Qufu and Laixi. They have similar annual average temperatures $\left(13.6\right.$ and $\left.11.7^{\circ} \mathrm{C}\right)$ and average precipitations (666 and $636 \mathrm{~mm}$, of which $60-70 \%$ occurs in summer). The soil type in Qufu and Laixi is brown soil (one of the most prevalent soil types in northern China), comprising ca. $13.8 \%$ clay, $57.7 \%$ silt, and $28.7 \%$ sand.

\section{Sampling Campaign}

In each study area, we set a farmland plot $\left(120 \mathrm{~m}^{2}\right)$ and a wasteland $\left(120 \mathrm{~m}^{2}\right.$, ca. $300 \mathrm{~m}$ away from the farmland). These two land types have similar elevations and topographies. Farmlands in Qufu and Laixi have been cultivated for thousands of years, with double cropping of summer maize (Zea mays L.) and winter wheat (Triticum aestivum L.). Nitrogenous fertilizer and composite fertilizer were generally used with ca. $750 \mathrm{~kg}$ per ha per season. After harvest, wheat stubble and maize root are chopped and evenly distributed on the farmland's soil surface. Soil is plowed with the chopped straw to $15 \sim 20 \mathrm{~cm}$ depth. Local farmers have employed this straw-return treatment in Qufu and Laixi since 2008. The wastelands selected have never been cultivated in both Qufu and Laixi.

We conducted the sampling campaign every June and October from 2010 to 2012 in the selected farmland and wasteland plots. Each land plot was evenly divided 
a)

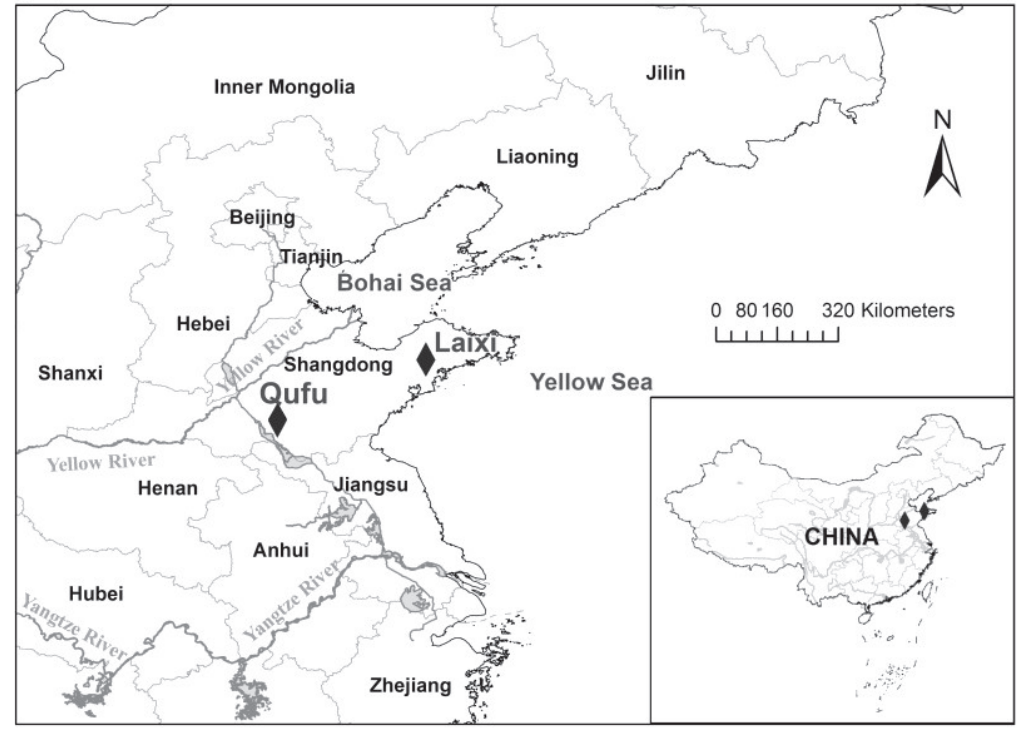

b)

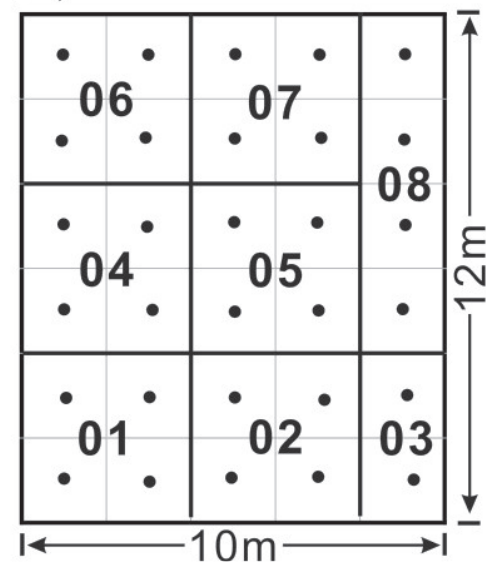

Fig. 1. Locations of Qufu and Laixi in Shandong, North China Plain a), and the sampling sketch for surface soils b) in farmland and wasteland. Subsamples $(\bullet)$ were collected and homogenized to form a sample. In each land, eight surface soil samples were collected.

into eight grids (Fig. 1b). In each grid, four surface subsoils $(0 \sim 20 \mathrm{~cm})$ were collected with a clean stainless steel shovel and homogenized to form a representative soil sample. Besides, we collected one soil column $(180 \mathrm{~cm})$ at the same spot in each land plot every year. All soil columns were sliced into $5-\mathrm{cm}$ slices for the top layer $(0 \sim 20 \mathrm{~cm})$ and $10-\mathrm{cm}$ slices for the sub-layer $(>20 \mathrm{~cm})$ on site.

\section{Sample Preparation and Instrumental Analysis}

Soil samples were prepared and analyzed at the laboratories in the Institute of Geophysical and Geochemical Exploration, Chinese Academy of Geological Sciences, China. Each soil sample was air-dried, grind, and passed through a 2-mm sieve. The SOC concentration was determined by the $\mathrm{K}_{2} \mathrm{Cr}_{2} \mathrm{O}_{7}$ oxidation and titration method. Briefly, each soil $(500 \mathrm{mg}$ ) was placed in a tube, added $10 \mathrm{~mL}$ of $1.00 \mathrm{~mol} / \mathrm{L} \mathrm{K}_{2} \mathrm{Cr}_{2} \mathrm{O}_{7}$ and $20 \mathrm{~mL}$ of concentrated $\mathrm{H}_{2} \mathrm{SO}_{4}$, and digested for $30 \mathrm{~min}$. After dilution, few drops of $o$-phenanthroline were added into the diluted digest and titrated with the $\mathrm{Fe}\left(\mathrm{NH}_{4}\right)_{2}\left(\mathrm{SO}_{4}\right)_{2} \cdot 6 \mathrm{H}_{2} \mathrm{O}$ solution.

In addition, we analyzed $\mathrm{pH}$ with potentiometry method; As with hydride generation-atomic fluorescence spectrometry (HG-AFS) method; Hg with cold vapor atomic fluorescence spectrometry (CV-AFS) method; $\mathrm{Cd}, \mathrm{Cu}, \mathrm{Ni}, \mathrm{Zn}$, and $\mathrm{Pb}$ with inductively coupled plasma mass spectrometry (ICP-MS) method; and $\mathrm{Cr}$, $\mathrm{SiO}_{2}, \mathrm{Al}_{2} \mathrm{O}_{3}, \mathrm{TFe}_{2} \mathrm{O}_{3}, \mathrm{MgO}, \mathrm{CaO}, \mathrm{Na}_{2} \mathrm{O}$, and $\mathrm{K}_{2} \mathrm{O}$ with $\mathrm{X}$-ray fluorescence spectrometer method. Standard reference materials, blanks, and duplicate samples were used to guarantee the accuracy of the experimental measurements.

\section{Data Analysis}

All data reported in our study were on a dry weight basis. We used IBM SPSS 25 software to perform statistical analysis. Specifically, the Mann-Whitney test and Wilcoxon signed-rank test were used to examine the differences between surface SOC concentrations and between vertical SOC concentrations in different lands. The influences of land use, soil properties, and climatic conditions on the SOC distributions were quantified by principal component analysis and multiple linear regression analysis (PCA+MLRA).

\section{Results and Discussion}

Spatial Distribution of SOC

The SOC concentrations in surface soils ranged from 1.84 27.4 $\mathrm{g} / \mathrm{kg}$, with the mean $\pm \mathrm{SD}$ (standard deviation) of $10.0 \pm 3.64 \mathrm{~g} / \mathrm{kg}$ (Table 1). The coefficient of variation $(\mathrm{CV})$ of SOC in surface soils was $36.2 \%$. All high SOC concentrations $(>15 \mathrm{~g} / \mathrm{kg})$ were observed in the wasteland.

In soil profile, the average SOC concentrations ranged from 1.82 9.33 $\mathrm{g} / \mathrm{kg}$, with the mean $\pm \mathrm{SD}$ of $3.28 \pm 1.74 \mathrm{~g} / \mathrm{kg}$ (Table 1). The SOC concentrations decreased with the soil depth, with an initial rapid decrease in shallow layers $(0 \sim 40 \mathrm{~cm})$ followed by a slight decrease in $40 \sim 180 \mathrm{~cm}$ soil layers (Fig. 2). This vertical variation pattern was generally observed in soil profiles in previous studies [22, 23], although the change point from rapid decrease to slow decrease might be different from ours. The mean concentrations of SOC in different layers were in the order of $0 \sim 20 \mathrm{~cm}$ 


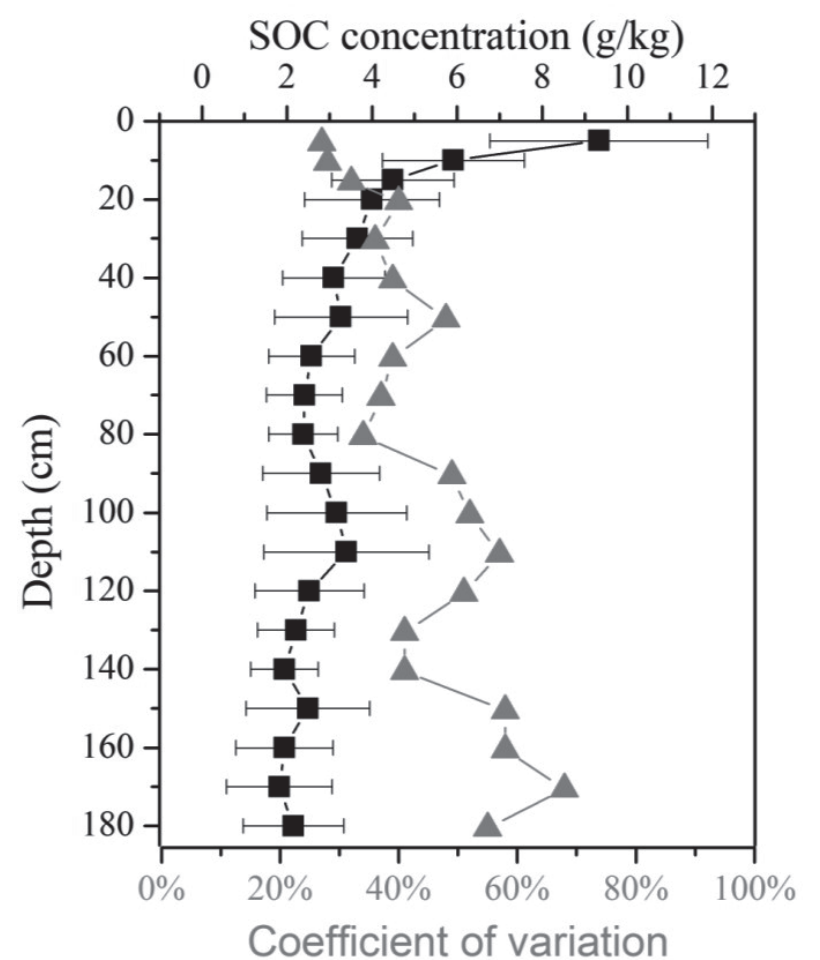

Fig. 2. The average SOC concentrations (- - ) and coefficient of variation values $(-)$ in the soil columns. Error bars were standard deviations.

$(5.93 \mathrm{~g} / \mathrm{kg})>0 \sim 100 \mathrm{~cm}(3.92 \mathrm{~g} / \mathrm{kg})>0 \sim 180 \mathrm{~cm}(3.28 \mathrm{~g} / \mathrm{kg})$. This, accompanied by the high SOC concentrations in surface soils $(10.0 \pm 3.64 \mathrm{~g} / \mathrm{kg})$, indicated that SOC mostly accumulated in topsoil layers, which is in line with numerous studies $[1,23]$. However, the SOC stock in the surface $0 \sim 20 \mathrm{~cm}$ layers merely accounted for ca.
$36.2 \%$ of the total SOC stock in the whole soil profile, based on the assumption that the soil density was the same in every soil layer. This result is highly consistent with the estimation that the subsoil layers $(20 \sim 300 \mathrm{~cm})$ contained more than two-thirds of SOC globally [18]. The $\mathrm{CV}$ values for SOC in soil profile ranged from 27.4 to $68.4 \%$, following an increasing trend with the increasing depth (Fig. 2). The relatively small CV values were observed in the top $0 \sim 20 \mathrm{~cm}$ layers $(<40 \%$, Fig. 2). Yu et al. (2020) [23] also reported the lower variability of SOC in the $0 \sim 20 \mathrm{~cm}$ soil layers (52\%) compared with deeper layers in a small watershed in Loess Plateau, China. They attributed it to the main influence of litter input on the SOC transformation and accumulation in the surface soil, and the artificial revegetation. These are also capable of explaining the lower variability in the topsoil layer herein. In our study, litter input is the main carbon source both in farmland and wasteland. Besides, the intense cultivation in farmland homogenizes the shallow soil layers.

\section{Effect of Land Use on SOC}

\section{SOC in Surface Soil}

SOC concentrations in farmland surface soils were in the range (mean \pm SD) of $5.30 \sim 14.7(8.95 \pm 1.86) \mathrm{g} / \mathrm{kg}$ (Fig. 3a). Compared with SOC concentrations in farmland under straw-return treatment with similar cropping system in other areas of northern China, the SOC in farmland surface soils herein under 4-year strawreturn treatment were lower than those in Northeast China (21.4 g/kg, ten years) [24]; but higher than those in Yinchuan, Ningxia (6.7 g/kg, 13 years) [25], a)

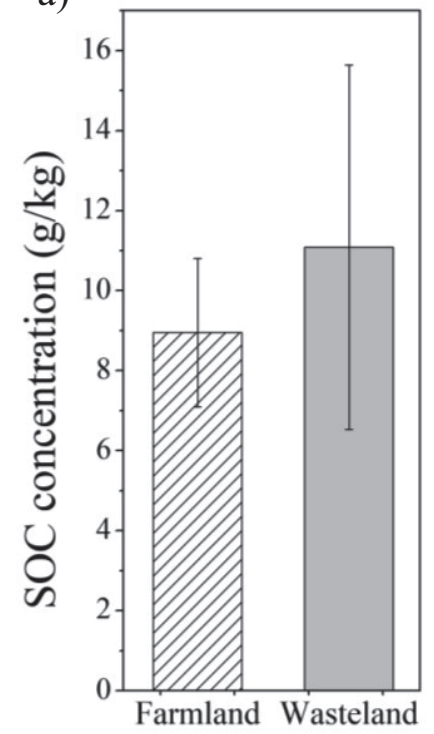

b)

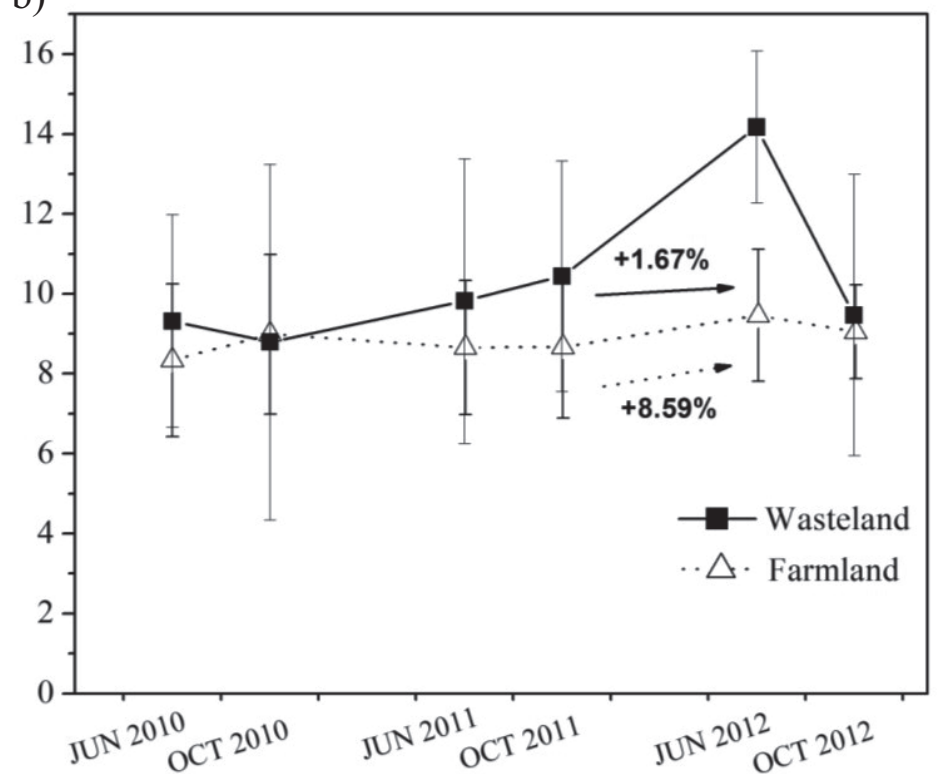

Fig. 3. The average SOC concentrations a) and temporal variations of SOC b) in surface soils in farmland and wasteland. Error bars were standard deviations. 
Changping, Beijing (7.1 g/kg, 15 years), Zhengzhou, Henan $(6.6 \mathrm{~g} / \mathrm{kg}, 18$ years) $[26,27]$ and Quzhou, Hebei (4.1 g/kg, 16 years) [28]. These comparisons showed a medium level for SOC concentration in farmland in our study areas.

In the wasteland, SOC concentrations ranged from 1.84 to $27.4 \mathrm{~g} / \mathrm{kg}$, with the mean $\pm \mathrm{SD}$ of $11.1 \pm 4.55 \mathrm{~g} / \mathrm{kg}$ (Fig. 3a), which were significantly higher than those in farmland (Mann-Whitney test, $p<0.001$ ), indicating the significant influence of land use on SOC in surface soils. Compared with wasteland, the SOC concentrations in farmland surface soils decreased by avg. $18.9 \%$ (Fig. 3a), which suggested the apparent loss of SOC in farmland due to the intensive tillagebased production [29]. Nevertheless, the loss percentage of SOC in farmland after cultivation for thousands of years in our study is much lower than those (40 60\%) reported for in farmland in the Midwestern U.S. during the 20th century $[30,31]$ and that (nearly 45\%) in Northeast China after 300 years cultivation [10].

As shown in Fig. 3b), the SOC concentrations in farmland surface soils experienced slow but steady growth (CV: $4.43 \%)$, with an overall increased rate of $8.59 \%$ over three years. Differently, SOC in wasteland surface soils fluctuated over time (CV: 19.0\%) and merely increased by $1.67 \%$ overall. These results indicated the effectiveness of straw-return treatment on the carbon sequestration and stabilization in surface soils, which have also been proved by numerous studies $[1,24]$.

\section{SOC in Soil Columns}

SOC concentrations in farmland and wasteland columns were in ranges (mean $\pm \mathrm{SD}$ ) of 1.89 8.17 $(3.38 \pm 1.49)$ and $1.55 \sim 10.5(3.17 \pm 2.04) \mathrm{g} / \mathrm{kg}$, respectively (Fig. 4a). Although the average SOC concentrations in farmland and wasteland columns were similar, the Wilcoxon Signed-rank test $(p<0.05)$ showed significantly higher SOC concentrations in the farmland columns (Fig. 4a).

Over time, the SOC concentrations significantly increased in both farmland and wasteland columns (Fig. 4b) and c), Wilcoxon Signed-rank, $p<0.05$ ). Compared with 2010, the SOC concentrations in farmland and wasteland columns in 2012 increased by $-8.88 \sim 292 \%$ (avg. 74.8\%) and -43.3 540\% (avg. 130\%), respectively. To the best of our knowledge, no studies reported such dramatic increases in SOC concentrations in soil columns over three years. This might be because most previous studies on SOC's temporal variations were carried on the shallow soil layers, while the distinct increase of SOC may only be observed in deep soil layers. For example, Dikgwatlhe et al. (2014) [1] assessed the SOC's temporal variations in $0 \sim 50 \mathrm{~cm}$ columns under different tillage and residue management systems in the North China Plain from 2004 to 2012. Their results showed the increase of SOC stock by $<28.8 \%$ over nine years. In our study, the SOC's remarkable increases were observed in 30 180 and $80 \sim 180 \mathrm{~cm}$ layers, with the highest increases observed in the $170 \mathrm{~cm}$ and $150 \mathrm{~cm}$ layers in the farmland and wasteland (Fig. 4b and c), respectively. Higher increases of SOC in deep layers compared with shallow layers in both farmland and wasteland can be attributed to the less soil disturbance and reduced litter decomposition. The SOC concentrations in wasteland varied more significantly with the depth in 2012 compared with those in farmland. The less homogeneous soil can explain this in the wasteland without the long-term mechanical cultivation. Furthermore, lower animals (e.g., insects and invertebrates) are not disturbed by human activities in the wasteland. The movement of animals in the soil will create advantageous pathways for the SOC downward migration. On the contrary, fertilization, irrigation, and pesticide application in farmland might significantly decrease insects and invertebrates and change the animal communities in the farmland soil.

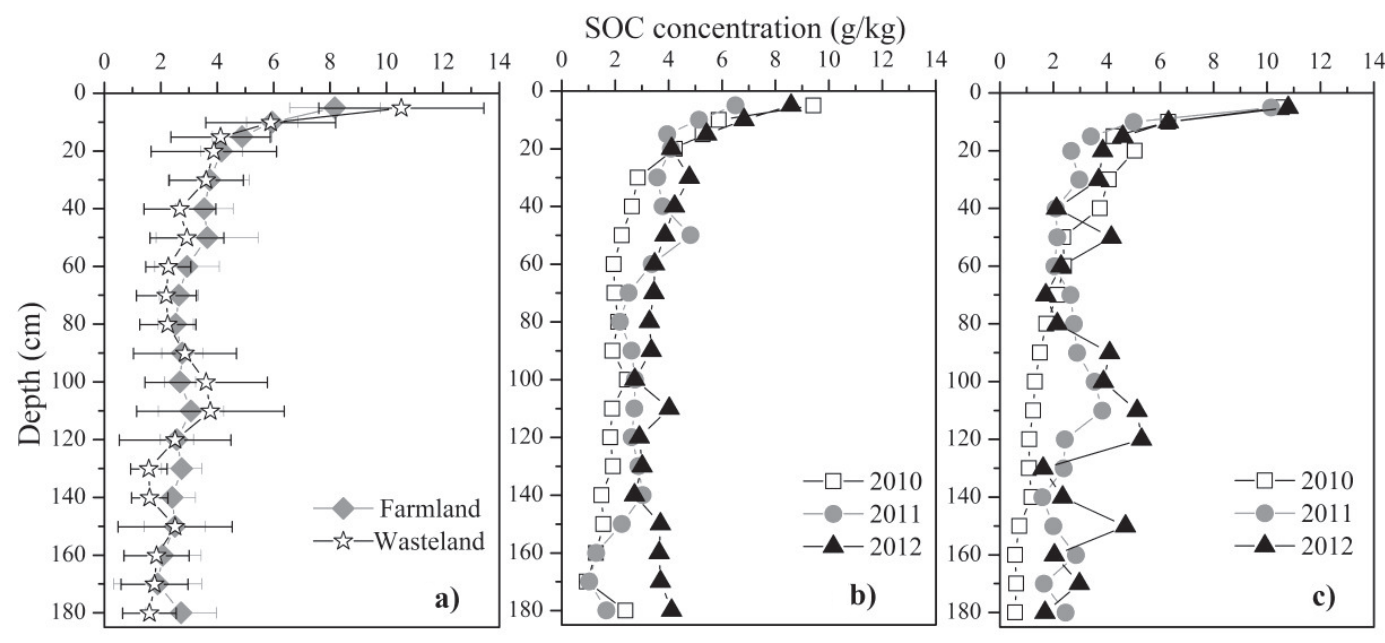

Fig. 4. The vertical distributions of SOC a), and temporal variations of SOC in soil columns in farmland b) and wasteland c). Error bars were standard deviations. 
It is worth noting the significant effectiveness of straw-return treatment in farmland on increasing SOC concentrations in the soil profile. The dramatic increase of SOC in soil profiles in farmland could be explained by the increased carbon input in farmland under straw-return treatment, the enhanced SOC leaching due to the agricultural activities, and the reduced SOC decomposition in deep soil layers. (I) The treatment of straw-return in fields could significantly increase the labile, dissolved, particulate, and microbial biomass carbons in the soil [24]. (II) Among those fractions, dissolved organic carbon could readily leach to the deeper soil layers, especially in agricultural land. Brye et al. (2001) [32] reported that the dissolved carbon leaching increased by more than five times in 4 years in agricultural soils growing maize and under cultivation with fertilization and plowing. (III) More importantly, the SOC is prone to be accumulated in the deep soil layer because of the reduced exposure and SOC decomposition [19, 33]. The slow turnover rate of carbon in subsoil was evidenced by the high ages of ${ }^{14} \mathrm{C}-\mathrm{SOC}$ [19]. Our results highlighted that the effect of straw-return on SOC sequestration might be vastly underestimated in studies only carried on the surface soil. Subsoil layers $(20 \sim 300$ $\mathrm{cm})$ contain more than two-thirds of SOC within the soil profile globally [18]. Thus, the increased SOC concentration in the subsoil is more important than that in surface soil in the aspect of mitigating climate change by reducing the increase in atmospheric $\mathrm{CO}_{2}$ concentration.

\section{Effect of Soil Conditions on SOC}

$$
\mathrm{pH}
$$

In our study, $\mathrm{pH}$ in surface soil ranged from 4.22 to 7.92 , with a mean of 5.47 (Table 1), indicating the soil acidification in the study areas. A more specific analysis showed a significantly lower $\mathrm{pH}$ values in farmland surface soils (range: 4.22 6.81, avg. 5.02) than those in wasteland surface soils (range: 4.59 7.92, avg. 5.92) (Mann-Whitney test, $p<0.001$ ). Our result suggested that (1) the acid rains probably occurred and lead to soil acidification in our study areas. Acid rains have frequently been observed in northern China in recent years [34], although they are weaker than those in south China [35]; and (2) cultivation-related activities promoted the soil acidification. In our study areas, nitrogen fertilizer (urea) is mainly utilized in farmland, with the usage rate of ca. $1500 \mathrm{~kg}$ per ha per year. The application of nitrogen fertilizer can lead to soil acidification by directly releasing protons $[36,37]$ and contributing $\mathrm{H}^{+}$to soil [38]. Moreover, the stimulation of crop growth by nitrogen fertilizer will enhance the uptake of base cations, in which the equivalent protons will be released $[36,37]$. In soil columns, $\mathrm{pH}$ ranged

Table 1. The concentrations of SOC $(\mathrm{g} / \mathrm{kg}), \mathrm{pH}$, heavy metals $(\mathrm{mg} / \mathrm{kg})$ and minerals $(\mathrm{g} / \mathrm{kg})$ in surface soils and soil columns.

\begin{tabular}{|c|c|c|c|c|c|c|}
\hline & \multicolumn{3}{|c|}{ Surface soils } & \multicolumn{3}{|c|}{ Soil columns } \\
\hline & Range & Median & Mean \pm SD & Range & Median & Mean \pm SD \\
\hline SOC & $1.84-27.4$ & 9.88 & $10.0 \pm 3.64$ & $1.82-9.33$ & 2.69 & $3.28 \pm 1.74$ \\
\hline $\mathrm{pH}$ & $4.22-7.92$ & 5.45 & $5.47 \pm 0.73$ & $4.60-7.47$ & 6.74 & $6.66 \pm 0.57$ \\
\hline As & $4.13-33.8$ & 6.22 & $7.65 \pm 4.21$ & $0.38-31.4$ & 7.42 & $9.69 \pm 6.09$ \\
\hline $\mathrm{Cd}$ & $0.05-0.24$ & 0.11 & $0.11 \pm 0.03$ & $0.03-0.15$ & 0.06 & $0.07 \pm 0.03$ \\
\hline $\mathrm{Cr}$ & $28-98.2$ & 48.7 & $50.7 \pm 13.2$ & $16.3-122$ & 55.1 & $57.9 \pm 23.5$ \\
\hline $\mathrm{Cu}$ & $12.9-144$ & 19.6 & $20.7 \pm 10.7$ & $8.25-40.7$ & 19.3 & $20.7 \pm 6.88$ \\
\hline $\mathrm{Hg}$ & $0.02-0.25$ & 0.03 & $0.05 \pm 0.03$ & 0.01-0.39 & 0.02 & $0.05 \pm 0.07$ \\
\hline $\mathrm{Ni}$ & $13.5-58.2$ & 19.3 & $22.0 \pm 8.28$ & $8.55-87.5$ & 23.3 & $29.0 \pm 18.1$ \\
\hline $\mathrm{Pb}$ & $17.4-32.5$ & 22.3 & $22.6 \pm 2.86$ & $15.1-56.4$ & 21.2 & $22.6 \pm 5.53$ \\
\hline $\mathrm{Zn}$ & $31.5-88.9$ & 47.4 & $48.0 \pm 11.0$ & $23.0-194$ & 48.3 & $56.3 \pm 31.6$ \\
\hline $\mathrm{SiO}_{2}$ & $480-792$ & 666 & $660 \pm 51.8$ & 446-727 & 638 & $621 \pm 58.9$ \\
\hline $\mathrm{Al}_{2} \mathrm{O}_{3}$ & 84.8-196 & 124 & $122 \pm 19.8$ & $90.1-229$ & 135 & $141 \pm 28.2$ \\
\hline $\mathrm{TFe}_{2} \mathrm{O}_{3}$ & $21.1-89.3$ & 35.3 & $37.8 \pm 11.3$ & $19.1-107$ & 41.8 & $47.6 \pm 20.5$ \\
\hline $\mathrm{MgO}$ & $4.60-17.2$ & 9.20 & $9.29 \pm 2.52$ & $4.70-84.7$ & 13.0 & $15.5 \pm 10.9$ \\
\hline $\mathrm{CaO}$ & $5.90-18.9$ & 12.5 & $12.8 \pm 3.5$ & $6.30-20.8$ & 12.1 & $13.6 \pm 4.12$ \\
\hline $\mathrm{Na}_{2} \mathrm{O}$ & $2.90-29.7$ & 19.4 & $18.4 \pm 5.91$ & $0.90-43.09$ & 17.7 & $16.9 \pm 9.99$ \\
\hline $\mathrm{K}_{2} \mathrm{O}$ & $11.4-30.9$ & 24.9 & $22.9 \pm 5.54$ & $3.82-31.8$ & 20.4 & $21.6 \pm 6.28$ \\
\hline
\end{tabular}



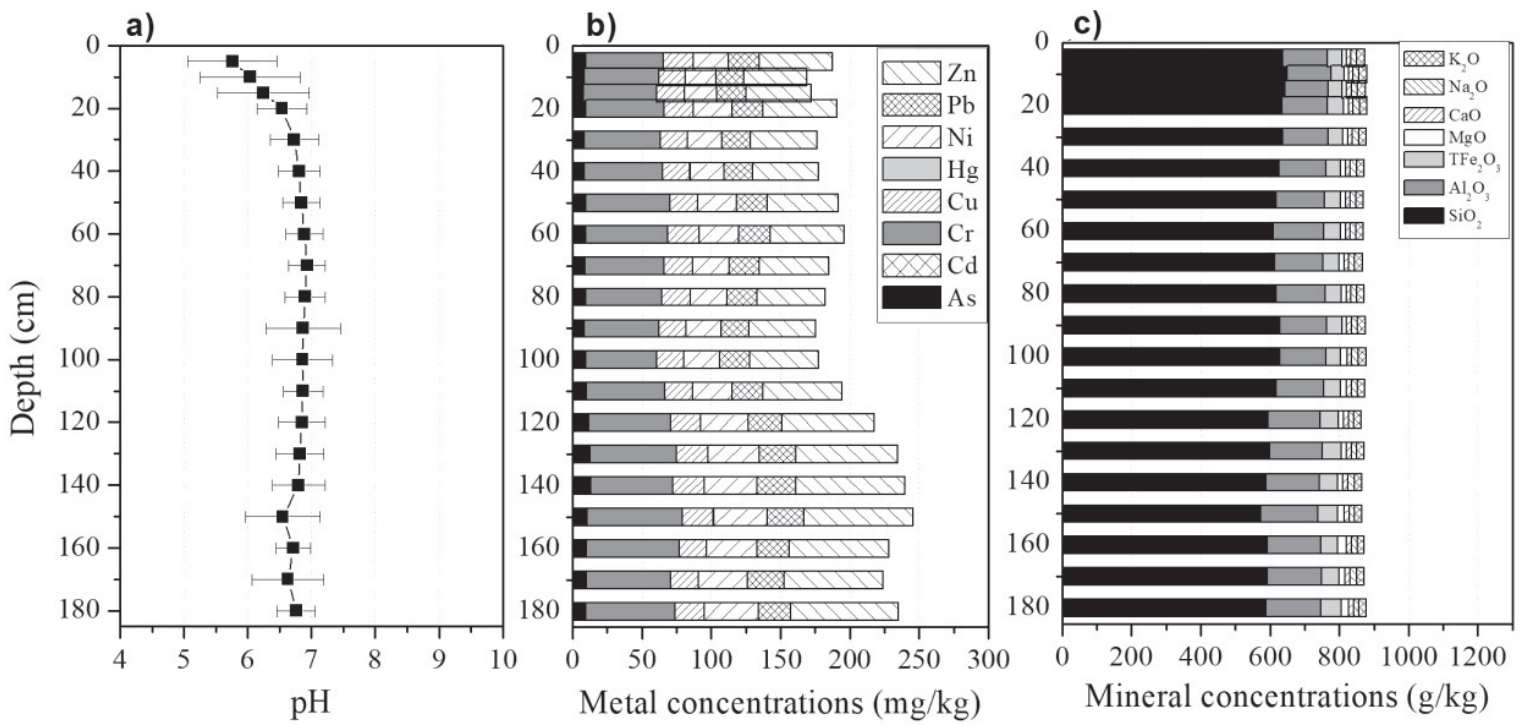

Fig. 5. The average $\mathrm{pH}$ a) and concentrations of heavy metals b) and minerals c) across the soil columns. Error bars were standard deviations.

from 4.60 to 7.47 (Table 1). $\mathrm{pH}$ values increased with the soil depth in the top $0 \sim 40 \mathrm{~cm}$ layers while they were relatively stable in 40-180 cm soil layers (Fig. 5a), showing that the soil acidification only occurred in the topsoil layers.

Generally, SOC concentrations tend to increase with decreasing soil $\mathrm{pH}$, as the low $\mathrm{pH}$ depresses the decomposition of organic matter by reducing microbial activity and increasing the protection of minerals [13]. The response of SOC to soil $\mathrm{pH}$ might vary significantly in different regions due to the various soil properties. In our study, $\mathrm{pH}$ values in surface soils significantly correlated with SOC concentrations (Pearson correlation analysis, $p=0.007$, Table 2). However, this correlation was positive. In addition, the linear regression between $\mathrm{pH}$ and $\mathrm{SOC}$ showed

Table 2. Pearson correlations between SOC and $\mathrm{pH}$, heavy metals and minerals in surface soils and soil columns.

\begin{tabular}{|c|c|c|c|c|c|}
\hline & & \multicolumn{2}{|c|}{ SOC in surface soils } & \multicolumn{2}{|c|}{ SOC in soil columns } \\
\hline & & Pearson correlation & Sig. (2-tailed) & Pearson correlation & Sig. (2-tailed) \\
\hline $\mathrm{pH}$ & & $0.193 * *$ & 0.007 & $-0.646^{* *}$ & 0.000 \\
\hline \multirow{8}{*}{$\begin{array}{l}\text { Heavy } \\
\text { metals }\end{array}$} & As & $-0.284 * *$ & 0.000 & -0.010 & 0.917 \\
\hline & $\mathrm{Cd}$ & $0.572 * *$ & 0.000 & $0.271 * *$ & 0.000 \\
\hline & $\mathrm{Cr}$ & $-0.480 * *$ & 0.000 & 0.000 & 0.258 \\
\hline & $\mathrm{Cu}$ & 0.080 & 0.256 & -0.090 & 0.192 \\
\hline & $\mathrm{Hg}$ & -0.120 & 0.088 & -0.090 & 0.217 \\
\hline & $\mathrm{Ni}$ & $-0.266^{* *}$ & 0.000 & $-0.166^{*}$ & 0.018 \\
\hline & $\mathrm{Pb}$ & $0.263^{* *}$ & 0.000 & $-0.157^{*}$ & 0.026 \\
\hline & $\mathrm{Zn}$ & 0.090 & 0.209 & $-0.203 * *$ & 0.004 \\
\hline \multirow{8}{*}{ Minerals } & $\mathrm{SiO}_{2} / \mathrm{Al}_{2} \mathrm{O}_{3}$ & -0.054 & 0.453 & $0.376^{* *}$ & 0.000 \\
\hline & $\mathrm{SiO}_{2}$ & -0.130 & 0.070 & $0.336^{* *}$ & 0.000 \\
\hline & $\mathrm{Al}_{2} \mathrm{O}_{3}$ & -0.100 & 0.150 & $-0.322 * *$ & 0.000 \\
\hline & $\mathrm{TFe}_{2} \mathrm{O}_{3}$ & $-0.184^{*}$ & 0.011 & $-0.165^{*}$ & 0.019 \\
\hline & $\mathrm{MgO}$ & $0.231 * *$ & 0.001 & $-0.142 *$ & 0.044 \\
\hline & $\mathrm{CaO}$ & $0.576^{* *}$ & 0.000 & $-0.211 * *$ & 0.003 \\
\hline & $\mathrm{Na}_{2} \mathrm{O}$ & $0.395 * *$ & 0.000 & -0.083 & 0.242 \\
\hline & $\mathrm{K}_{2} \mathrm{O}$ & $0.521 * *$ & 0.000 & -0.053 & 0.455 \\
\hline
\end{tabular}

*Correlation is significant at the 0.05 level (2-tailed).

**Correlation is significant at the 0.01 level (2-tailed). 
Table 3. Correlations between climatic conditions and SOC in surface soils and soil columns.

\begin{tabular}{|c|c|c|c|c|c|}
\hline & \multicolumn{2}{|c|}{ Precipitation } & \multicolumn{2}{c|}{ Temperature } \\
\hline & Pearson correlation & Sig. (2-tailed) & Pearson correlation & Sig. (2-tailed) \\
\hline \multicolumn{2}{|c|}{ SOC in surface soils } & 0.086 & 0.792 & -0.056 & 0.863 \\
\hline \multirow{3}{*}{$\begin{array}{c}\text { SOC in soil } \\
\text { columns }\end{array}$} & $0-20 \mathrm{~cm}$ & -0.762 & 0.078 & -0.503 & 0.309 \\
\cline { 2 - 6 } & $0-100 \mathrm{~cm}$ & $\mathbf{- 0 . 9 5 0 * *}$ & 0.004 & -0.180 & 0.733 \\
\cline { 2 - 6 } & $0-180 \mathrm{~cm}$ & $\mathbf{- 0 . 8 2 0 *}$ & 0.046 & 0.387 & 0.448 \\
\hline
\end{tabular}

*Correlation is significant at the 0.05 level (2-tailed).

$* *$ Correlation is significant at the 0.01 level (2-tailed).

a useless $\mathrm{R}^{2}$ value (0.04), implying the minor influence of $\mathrm{pH}$ on SOC concentrations in surface soils in our study. The non-significant relationship between soil $\mathrm{pH}$ and SOC was also observed in surface soils in Northeast China [13]. Differently, pH was significantly negatively correlated with SOC in soil columns (Pearson correlation analysis, $\mathrm{r}=-0.646, p<0.001$, Table 2), with a moderate $\mathrm{R}^{2}$ of 0.42 , showing the significant influence of $\mathrm{pH}$ on the vertical distribution of SOC.

\section{Heavy Metals}

The total concentrations of $\mathrm{As}, \mathrm{Cd}, \mathrm{Cr}, \mathrm{Cu}$, $\mathrm{Hg}, \mathrm{Ni}, \mathrm{Pb}$, and $\mathrm{Zn}\left(\sum \mathrm{HM}\right)$ in surface soils ranged $125 \sim 377 \mathrm{mg} / \mathrm{kg}$, with a mean of $171 \mathrm{mg} / \mathrm{kg}$. We summarized the concentrations of individual metals in surface soils in Table $1 . \mathrm{Cr}$ and $\mathrm{Zn}$ were the most dominant metals, accounting for avg. 29.6 and 28.1\% of the $\sum \mathrm{HM}$, respectively. Further analysis showed significantly lower $\mathrm{Cd}, \mathrm{Cu}, \mathrm{Pb}$, and $\mathrm{Zn}$ in farmland than wasteland (Mann-Whitney test, $p<0.05$ ). Other metals were statically similar. The reduced concentrations of metals in farmland surface soils might imply the soil erosion in farmland due to the intensive cultivation. The phenomenon that no accumulation of heavy metals was observed in farmland surface soil agrees that mineral fertilizer and animal waste (the primary source of heavy metals in agriculture soil $[39,40]$ ) were not used in our study areas.

In soil columns, the average concentrations of $\sum \mathrm{HM}$ were in a range (mean) of 161 245 (190) mg/kg (Fig. 5b). As the most abundant metals, $\mathrm{Cr}$ and $\mathrm{Zn}$ accounted for avg. 29.7 and $28.2 \%$ of the $\sum H M$, respectively. The $\Sigma H M$ concentrations showed an increasing trend with the soil depth (Fig. 5b). The compositions of heavy metals were statistically similar across the soil profile (Mann-Whitney test, $p>0.05$ ) (Fig. 5b), indicating their similar sources.

Heavy metals could protect the SOC from degradation by alerting the microflora and decreasing the activities of microorganisms, which had been investigated in the past decades [41-43]. In our study, significant correlations between $\mathrm{SOC}$ and $\mathrm{As}, \mathrm{Cd}, \mathrm{Cr}$, $\mathrm{Ni}$, and $\mathrm{Pb}$ were found in surface soils (Table 2). In the soil column, $\mathrm{Cd}, \mathrm{Ni}, \mathrm{Pb}$, and $\mathrm{Zn}$ were significantly

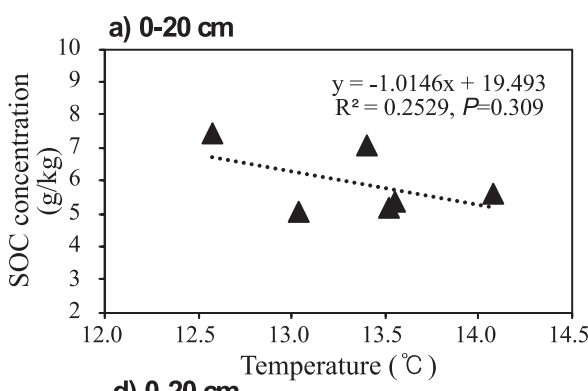

b) $0-100 \mathrm{~cm}$

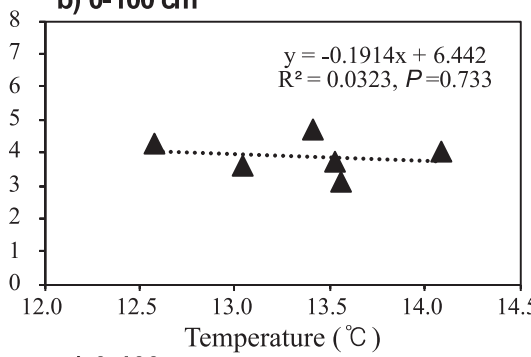

e) $0-100 \mathrm{~cm}$

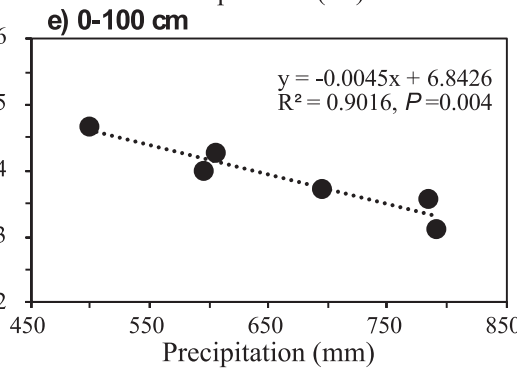

c) $0-180 \mathrm{~cm}$

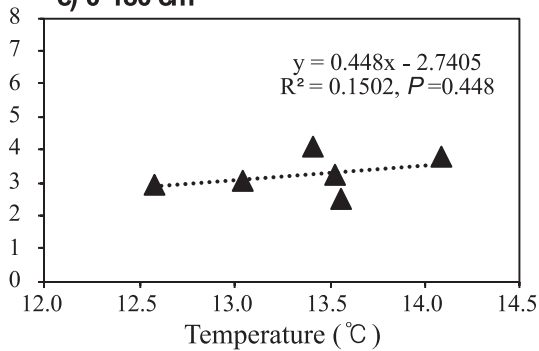

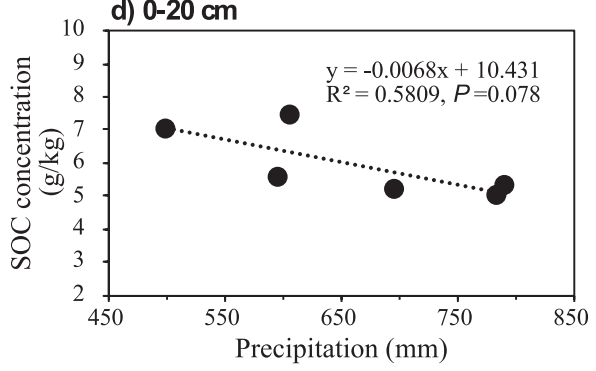

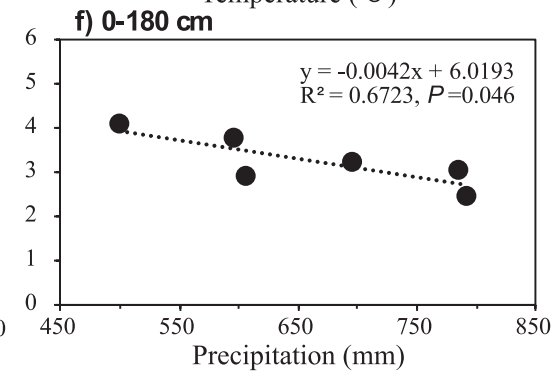

Fig. 6. Regression plots between SOC and precipitation and temperature in different soil layers. 
correlated with SOC (Table 2). These indicated the inevitable influences of heavy metals on the distribution of SOC in surface soil and soil profile.

\section{Minerals}

Seven minerals, including $\mathrm{SiO}_{2}, \mathrm{Al}_{2} \mathrm{O}_{3}, \mathrm{TFe}_{2} \mathrm{O}_{3}$, $\mathrm{MgO}, \mathrm{CaO}, \mathrm{Na}_{2} \mathrm{O}$, and $\mathrm{K}_{2} \mathrm{O}$, were analyzed in our study. $\mathrm{SiO}_{2}$ and $\mathrm{Al}_{2} \mathrm{O}_{3}$ were the most abundant minerals both in surface soils and soil columns (Table 1). In the soil column, the mineral composition did not significantly change with the soil depth (Mann-Whitney test, $p>0.05$, Fig. 5c).

Attachment of organic matter to mineral surfaces is a primary stabilization mechanism for $\mathrm{SOC}$ in soil $[3,44]$. Generally, the mass ratio of $\mathrm{Al}_{2} \mathrm{O}_{3} / \mathrm{SiO}_{2}$ highly correlates with soil texture and could partly represent the soil weathering degree. A high ratio of $\mathrm{Al}_{2} \mathrm{O}_{3} / \mathrm{SiO}_{2}$ suggests high soil clay [45]. In our study, the significant correlation between $\mathrm{SOC}$ and $\mathrm{Al}_{2} \mathrm{O}_{3} / \mathrm{SiO}_{2}$ was found in soil profiles $(p<0.001$, Table 2$)$, while not in surface soils ( $p>0.05$, Table 2$)$. For individual minerals, significant correlations between $\mathrm{SOC}$ and $\mathrm{TFe}_{2} \mathrm{O}_{3}, \mathrm{MgO}$, $\mathrm{CaO}, \mathrm{Na}_{2} \mathrm{O}$, and $\mathrm{K}_{2} \mathrm{O}$ were observed in surface soils. All minerals (except for $\mathrm{Na}_{2} \mathrm{O}$ and $\mathrm{K}_{2} \mathrm{O}$ ) were significantly correlated with SOC $(p<0.05)$ in soil columns. We noticed that the SOC concentrations in surface soils were more strongly associated with $\mathrm{MgO}, \mathrm{CaO}, \mathrm{Na}_{2} \mathrm{O}$, and $\mathrm{K}_{2} \mathrm{O}$, while in soil columns, their correlations with $\mathrm{TFe}_{2} \mathrm{O}_{3}$ and $\mathrm{Al}_{2} \mathrm{O}_{3}$ were stronger (Table 2). The different controlling minerals for SOC in different soils could be attributed to SOC's various physicochemical protections between topsoil and subsoil layers [44]. SOC in surface soils may have a high content of the light-fraction OC, which consists of plant and animal residues at different decomposition stages. Thus, SOC was more closely related to $\mathrm{Mg}, \mathrm{Ca}$, and $\mathrm{K}$ (three essential macronutrients supporting the plant's growth). In subsoil layers, SOC has a higher content of the heavy-fraction OC, which consists of microbial residues [46]. The heavy fraction $\mathrm{OC}$ was found depending on oxalate-extractable $\mathrm{Al}$ and Fe [44], which might explain the stronger correlations between $\mathrm{SOC}$ in soil columns and $\mathrm{TFe}_{2} \mathrm{O}_{3}$ and $\mathrm{Al}_{2} \mathrm{O}_{3}$ in our study.

Generally, the positive correlations between SOC and minerals were expected. However, because of the exposure to organic compounds, such as oxalic acid released by roots [47], the stability of minerals may change. This might be plausible for explaining the negative correlations between several minerals (such as $\mathrm{Al}_{2} \mathrm{O}_{3}$ and $\mathrm{TFe}_{2} \mathrm{O}_{3}$ ) and SOC in our study.

\section{Effect of Climatic Conditions on SOC}

We obtained climatic data (temperature and precipitation) from the China Meteorological Data Service Center (http://data.cma.cn/en). The temperature and precipitation values for each time points were the average temperature and cumulative rainfall, respectively, at corresponding sampling intervals. For example, the temperature $\left(22.5^{\circ} \mathrm{C}\right)$ and precipitation $(621.1 \mathrm{~mm})$ for Oct-2010 in Qufu were the average temperature and accumulative precipitation from $1^{\text {st }}$ July 2010 to $31^{\text {st }}$ October 2010, respectively.

Temperature and precipitation affect carbon input and SOC decomposition in soil and are critical drivers of SOC storage at the global and regional scales [3]. A decreased SOC with increasing temperature was reported in numerous studies [48, 10, 49], as temperature widely affects the micro-decomposition of SOM [50]. Higher precipitation generally facilitates net primary productivity in terrestrial environments, favors the SOC stabilization on the mineral surface, and thus increases the SOC content. In our study, the temporal variations of SOC in surface soils did not significantly correlate with precipitation and temperature (Pearson correlation analysis, $p>0.05$, Table 3 ). At the regional scale, the effects of climatic conditions might be counterbalanced by land management [51, 3], which could explain the weak correlations between SOC and climatic conditions in surface soils in our study. Nevertheless, the slight increases of SOC were observed with higher precipitation and lower temperature (Table 3).

The variation of temperature was also not significantly correlated with the SOC's temporal variation in soil columns (Pearson correlation analyses, $p>0.05$, Table 3 ). Nevertheless, we observed the decrease of SOC in soil profile with increasing temperature, especially in topsoil layers (Fig. 6a-b, and c). Compared with temperature, the influence of precipitation was more prominent, indicated by its significant correlations with SOC in the 0-100 and 0-180 cm layers (Pearson correlation analyses, $p<0.05$, Table 3, Fig. 6e) and f). In the surface $0-20 \mathrm{~cm}$ soil layers, SOC distinctly decreased with higher precipitation $\left(r^{2}=0.58\right.$, Fig. $\left.6 \mathrm{~d}\right)$, although their significant correlation was not observed (Pearson correlation analyses, $p>0.05$, Table 3). These results suggested the critical influence of precipitation on the vertical distribution of SOC. It is worth noted that we observed the negative correlation between SOC and precipitation in the soil profile, which is opposite to the general trend - SOC increases with higher precipitation. Our study areas belong to dry areas, with the prevalence of brown soil, which has high permeability (porosity: 44.7-54.6\% [52]). In our study areas, the increase of precipitation might promote the migrate of SOC through the soil profile (i.e., leaching). More importantly, it probably could increase the turnover of SOC in the soil profile by increasing the soil moisture and resultant microbial activity [53] and thus lead to the decrease of SOC.

\section{Main Factors Controlling SOC Distribution}

The analysis above suggested that the land use, soil properties ( $\mathrm{pH}$, heavy metals, and minerals), and 
climatic conditions (temperature and precipitation) exerted significant effects on the SOC distributions in surface soils and soil profiles. To specify the dominant influence factors on the SOC distributions, we subsequently used the PCA+MLRA to extract the principal components (PCs) and quantified their contributions to the SOC. The detailed methodology for the PCA+MLRA was presented by Larsen and Baker (2003) [54]. Briefly, in our study, twenty original factors, including $\mathrm{pH}, \mathrm{As}, \mathrm{Cd}, \mathrm{Cr}, \mathrm{Cu}, \mathrm{Hg}, \mathrm{Ni}, \mathrm{Pb}, \mathrm{Zn}, \mathrm{SiO}_{2}$, $\mathrm{Al}_{2} \mathrm{O}_{3}, \mathrm{TFe}_{2} \mathrm{O}_{3}, \mathrm{MgO}, \mathrm{CaO}, \mathrm{Na}_{2} \mathrm{O}, \mathrm{K}_{2} \mathrm{O}$, precipitation, temperature, SOC in farmland, and SOC in wasteland were introduced into the PCA analysis to extract PCs with eigenvalues greater than one. Subsequently, the absolute factor scores of PCs were used as independent variables, and the SOC concentrations were used as dependent variables to run the MLRA.

\section{Surface Soil}

Four PCs were extracted for surface soils and accounted for $87.4 \%$ of the total variance. PC1 accounted for $39.1 \%$ of the total variance and included the high positive loadings of SOC in farmland and SOC in wasteland, indicating the effect of land use. We observed that most heavy metals and minerals (including $\mathrm{As}, \mathrm{Cr}, \mathrm{Hg}, \mathrm{Ni}, \mathrm{Cd}, \mathrm{Pb}, \mathrm{CaO}, \mathrm{Na}_{2} \mathrm{O}, \mathrm{K}_{2} \mathrm{O}$, and $\mathrm{MgO}$ ) were included in $\mathrm{PCl}$ due to their close associations with SOC under different soil management. PC2 and PC3 accounted for 19.2 and $18.7 \%$ of the total variance and represented the influences of $\mathrm{pH}$ and $\mathrm{SiO}_{2}$, and $\mathrm{Cu}, \mathrm{Zn}$, and $\mathrm{Al}_{2} \mathrm{O}_{3}$, respectively. Accounting for $10.4 \%$, PC4 consisted of precipitation and temperature and indicated the effect of climatic conditions.

The modeled SOC concentrations in surface soils by MLRA fitted well with the measured SOC concentrations $\left(\mathrm{R}^{2}=0.798\right)$. Four PCs representing the effects of land use, $\mathrm{pH}$ and $\mathrm{SiO}_{2}, \mathrm{Cu}, \mathrm{Zn}$ and $\mathrm{Al}_{2} \mathrm{O}_{3}$, and climatic conditions contributed avg. 41.5, 12.1, 0.81 and $45.6 \%$, respectively on the SOC distributions in surface soils (Fig. 7a). The contributions of land use and climatic conditions were predominant. Each effect's contributions were relatively constant with time, with the $\mathrm{CV}$ values of $<16.2 \%$ (Fig. $7 \mathrm{a}$ ).

\section{Soil Columns}

Four PCs were extracted from the PCA for SOC in soil columns, accounting for $87.0 \%$ of the total variance. PC1 accounted for $40.0 \%$ of the total variance and represented the effect of heavy metals and minerals. It has high or medium loadings on the majority of heavy metals and minerals, including As, $\mathrm{Cr}, \mathrm{Cu}, \mathrm{Hg}, \mathrm{Ni}, \mathrm{Pb}, \mathrm{Zn}, \mathrm{Al}_{2} \mathrm{O}_{3}, \mathrm{TFe}_{2} \mathrm{O}_{3}, \mathrm{MgO}, \mathrm{Na}_{2} \mathrm{O}$, and $\mathrm{K}_{2} \mathrm{O}$. This is different from surface soils, in which many heavy metals and minerals were included in the PC representing the effect of land use. PC2 and PC4 accounted for 21.3 and $11.1 \%$, respectively. Together they represented the effects of climatic conditions, as PC2 and PC4 had high loadings of temperature and precipitation, respectively. Accounting for $14.6 \%$, PC3 consisted of $\mathrm{pH}, \mathrm{SOC}$ in farmland, and SOC in wasteland, representing the effect of land use.

In soil columns, the modeled SOC concentrations from the MLRA highly fitted the measured SOC concentration $\left(\mathrm{R}^{2}=949\right)$. The contribution percentages of heavy metals and minerals (PC1), climatic conditions (PC2 and PC4), and land use (PC3) were avg. 19.1, 26.6, and $54.3 \%$, respectively. Like surface soil, land use was predominant, affecting the SOC's vertical distribution, as suggested by Jia et al. (2017) [55]. Compared with those in surface soil, the contributions of climatic a)

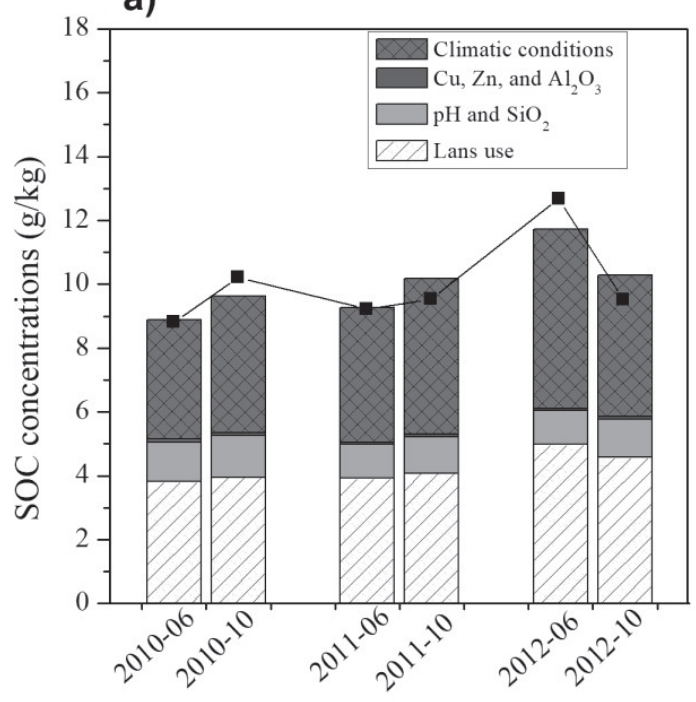

b)

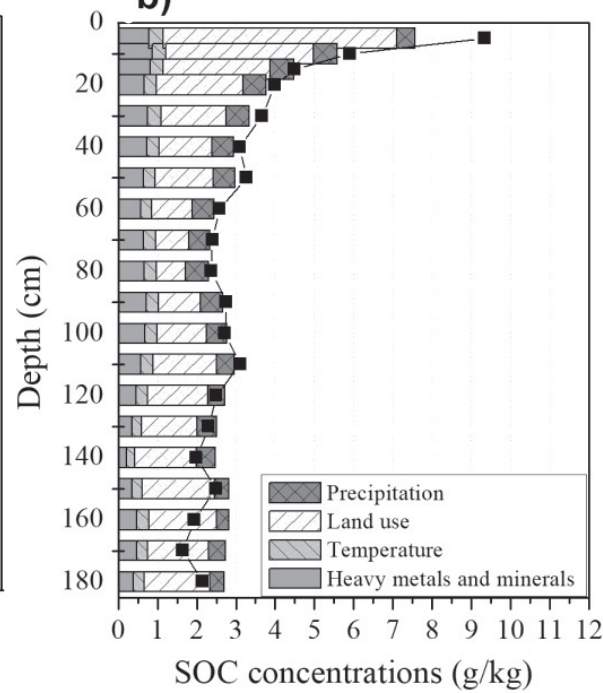

Fig. 7. Contributions for each proposed effect on the SOC distribution in the surface soil a) and soil column b) based on the principal component analysis + multiple linear regression analysis (PCA+MLRA). The symbol $\bullet$ represented the measured SOC concentrations. 
conditions were lower, and heavy metals and minerals contributed greater. The contributions of land use appeared to have the greatest variation across the soil profile. They ranged from 32.2 to $78.6 \%$, with a high $\mathrm{CV}$ of $54.3 \%$ (Fig. $7 \mathrm{~b}$ ). In the soil layer of $0 \sim 80 \mathrm{~cm}$, the contributions of land use distinctly decreased with the soil depth (CV: $74.3 \%$, Fig. 7b). The land use affected both the above-ground plant yields and botanical composition and underground root distribution and morphology [56], which were primarily responsible for the SOC accumulation in the subsoil $[6,57]$. The decrease of fine root biomass of herbage and crop (the dominant plants in farmland and wasteland in our study) with the soil depth $[6,57]$ explained the diminished contributions of land use with soil depth in $0-80 \mathrm{~cm}$ layers in our study. In the deeper soil layers $(80 \sim 180 \mathrm{~cm}$ in our study), the lower rates of SOC decompositions favor the carbon accumulation and restoration, although the carbon input was low. The contributions of heavy metals and minerals were constant across the soil profile, which were in line with the statically similar compositions of heavy metals and minerals among different soil layers (Fig. 7b).

\section{Conclusions}

In this study, we elaborated the influences of land use (farmland and wasteland), soil properties $(\mathrm{pH}$, eight heavy metals, and seven minerals), and climatic conditions (temperature and precipitation) on the spatiotemporal distributions of SOC in surface soils $(0 \sim 20 \mathrm{~cm})$ and soil columns $(0 \sim 180 \mathrm{~cm})$ in Qufu and Laixi, Shangdong, North China Plain. With ca. 65\% SOC stored in $20 \sim 180 \mathrm{~cm}$ layers and the dramatic increase of SOC in subsoil over three years, the SOC in subsoil was of greater significance with reference to the SOC storage assessment and land management for increasing SOC sequestration. The land use and climatic conditions controlled the SOC distributions, with the contribution percentages of avg. 41.5 and $45.6 \%$, respectively, in surface soils and $54.3 \%$ and $26.6 \%$, respectively, in soil columns. Our study showed the dominant influences of land use and climatic conditions on the SOC distributions.

\section{Acknowledgements}

This study is financially supported by the Ministry of Natural Resources of the People's Republic of China (the former Ministry of Land and Resources) (Project No. 121201006205) and State Key Laboratory of Organic Geochemistry, Guangzhou Institute of Geochemistry, Chinese Academy of Sciences (Grant No. SKLOG202008). We thank Prof. Hangxin Cheng, Mr. Fei Liu, and Mr. Yinghan Liu from the Institute of Geochemical and Geophysical Exploration, Chinese Academy of Geological Sciences, Prof. Yunhai Zhang from the Institute of Botany, Chinese Academy of Sciences, and Profs. Xugui Pang and Jincheng Zhan from Shandong Institute of Geological Survey, for their guidance on the sampling campaign and helpful comments on this manuscript.

\section{Conflict of Interest}

The authors declare no conflict of interest.

\section{References}

1. DIKGWATLHE S.B., CHEN Z., LAL R., ZHANG H., CHEN F. Changes in soil organic carbon and nitrogen as affected by tillage and residue management under wheatmaize cropping system in the North China Plain. Soil and Tillage Research, 144, 110, 2014.

2. GARTZIA-BENGOETXEA N., VIRTO I., ARIASGONZÁLEZ A., ENRIQUE A., FERNÁNDEZ-UGALDE O., BARRÉ P. Mineral control of organic carbon storage in acid temperate forest soils in the Basque Country. Geoderma, 358, 113998, 2020.

3. WIESMEIER M., URBANSKI L., HOBLEY E., LANG, B., VON LÜTZOW M., MARIN-SPIOTTA E., VAN WESEMAEL B., RABOT E., LIESS M., GARCIAFRANCO N., WOLLSCHLÄGER U., VOGEL H., KÖGEL-KNABNER I. Soil organic carbon storage as a key function of soils - A review of drivers and indicators at various scales. Geoderma, 333, 149, 2019.

4. POWERS J.S., SCHLESINGER W.H. Relationships among soil carbon distributions and biophysical factors at nested spatial scales in rain forests of northeastern Costa Rica. Geoderma, 109 (3), 165, 2002.

5. LI S., LI Y., LI X., TIAN X., ZHAO A., WANG S.J., WANG S.X., SHI J. Effect of straw management on carbon sequestration and grain production in a maize - wheat cropping system in Anthrosol of the Guanzhong Plain. Soil and Tillage Research, 157, 43, 2016.

6. CHANG R., FU B., LIU G., WANG S., YAO X. The effects of afforestation on soil organic and inorganic carbon: A case study of the Loess Plateau of China. CATENA, 95, 145, 2012.

7. POEPLAU C., DON A., VESTERDAL L., LEIFELD J., WESEMAEL B.V., SCHUMACHER J., GENSIOR A. Temporal dynamics of soil organic carbon after land-use change in the temperate zone - carbon response functions as a model approach. Global Change Biology, 17 (7), 2415, 2011.

8. LAL R., REICOSKY D.C., HANSON J.D. Evolution of the plow over 10,000 years and the rationale for no-till farming. Soil and Tillage Research, 93 (1), 1, 2007.

9. VILLAMIL M.B., NAFZIGER E.D. Corn residue, tillage, and nitrogen rate effects on soil carbon and nutrient stocks in Illinois. Geoderma, 253-254, 61, 2015.

10. WANG Y., WANG S., ADHIKARI K., WANG Q., SUI Y., XIN G. Effect of cultivation history on soil organic carbon status of arable land in northeastern China. Geoderma, 342, 55, 2019.

11. POST W.M., KWON K.C. Soil carbon sequestration and land-use change: processes and potential. Global Change Biology, 6 (3), 317, 2000. 
12. TIEMANN L.K., GRANDY A.S., ATKINSON E.E., MARIN-SPIOTTA E., MCDANIEL M.D. Crop rotational diversity enhances belowground communities and functions in an agroecosystem. Ecology Letters, 18 (8), 761, 2015.

13. ZHANG X., GUO J., VOGT R.D., MULDER J., WANG Y., QIAN C., WANG J., ZHANG X. Soil acidification as an additional driver to organic carbon accumulation in major Chinese croplands. Geoderma, 366, 114234, 2020.

14. LEJON D.P.H., MARTINS J.M.F., LÉVÊQUE J., SPADINI L., PASCAULT N., LANDRY D., MILLOUX M.J., NOWAK V., CHAUSSOD R., RANJARD L. Copper Dynamics and Impact on Microbial Communities in Soils of Variable Organic Status. Environmental Science \& Technology, 42 (8), 2819, 2008.

15. ZHANG C., NIE S., LIANG J., ZENG G., WU H., HUA S., LIU J., YUAN Y., XIAO, H., DENG L., XIANG H. Effects of heavy metals and soil physicochemical properties on wetland soil microbial biomass and bacterial community structure. Science of The Total Environment, 557-558, 785, 2016

16. LEHMANN J., KLEBER M. The contentious nature of soil organic matter. Nature, 528 (7580), 60, 2015.

17. BAKER J.M., OCHSNER T.E., VENTEREA R.T., GRIFFIS T.J. Tillage and soil carbon sequestration What do we really know? Agriculture, Ecosystems \& Environment, 118 (1-4), 1, 2007.

18. JOBBÁGY E.G., JACKSON R.B. The vertical distribution of soil organic carbon and its relation to climate and vegetation. Ecological Applications, 10 (2), 423, 2000.

19. RUMPEL C., KÖGEL-KNABNER I. Deep soil organic matter - a key but poorly understood component of terrestrial C cycle. Plant and Soil, 338 (1-2), 143, 2011.

20. QIU J. China faces up to groundwater crisis. Nature, 466 (7304), 308, 2010

21. LONG X., TIE X., CAO J., HUANG R., FENG T., LI N., ZHAO S., TIAN J., LI G., ZHANG Q. Impact of crop field burning and mountains on heavy haze in the North China Plain: a case study. Atmospheric Chemistry and Physics, 16, 9675, 2016.

22. PAN G., WU L., LI L., ZHANG X., GONG W., WOOD Y. Organic carbon stratification and size distribution of three typical paddy soils from Taihu Lake region, China. Journal of Environmental Sciences, 20 (4), 456, 2008.

23. YU H., ZHA T., ZHANG X., NIE L., MA L., PAN Y. Spatial distribution of soil organic carbon may be predominantly regulated by topography in a small revegetated watershed. CATENA, 188, 104459, 2020.

24. YAN S., SONG J., FAN J., YAN C., DONG S., MA C., GONG Z. Changes in soil organic carbon fractions and microbial community under rice straw return in Northeast China. Global Ecology and Conservation, 22, e00962. 2020.

25. TAN D. Effect of long-term application of potassium on soil K, crop yield and quality in selected soils from North China (PhD Thesis). Chinese Academy of Agricultural Sciences, China. 2007.

26. ZHAO B., LI X.Y., LI X.P., SHI X., HUANG S., WANG B., ZHU P., YANG X., LIU H., CHEN Y., POULTON P., POWLSON D., TODD A., PAYNE R. Long-Term Fertilizer Experiment Network in China: Crop Yields and Soil Nutrient Trends. Agronomy Journal, 102 (1), 216. 2010.

27. JIANG G., XU M., HE X., ZHANG W., HUANG S., YANG X., LIU H., PENG C., SHIRATO Y., IIZUMI T., WANG J., MURPHY D.V. Soil organic carbon sequestration in upland soils of northern China under variable fertilizer management and climate change scenarios. Global Biogeochemical Cycles, 28 (3), 319, 2014.

28. NIU L., HAO J., ZHANG B., NIU X. Influences of LongTerm Fertilizer and Tillage Management on Soil Fertility of the North China Plain. Pedosphere, 21 (6), 813, 2011.

29. DAS A., LAL R., PATEL D.P., IDAPUGANTI R.G., LAYEK J., NGACHAN S.V., GHOSH P.K., BORDOLOI J., KUMAR M. Effects of tillage and biomass on soil quality and productivity of lowland rice cultivation by small scale farmers in North Eastern India. Soil and Tillage Research, 143, 50, 2014.

30. JENNY H. Factors of soil formation: a system of quantitative pedology. Courier Corporation. 1944.

31. HAAS H.J., EVANS C.E. Nitrogen and Carbon Changes in Great plains Soils as Influenced by Cropping and Soil Treatments. 1957.

32. BRYE K.R., NORMAN J.M., BUNDY L.G., GOWER S.T. Nitrogen and carbon leaching in agroecosystems and their role in denitrification potential. Journal of Environmental Quality, 30 (1), 58, 2001.

33. LIANG Z., OLESEN J.E., JENSEN J.L., ELSGAARD L. Nutrient availability affects carbon turnover and microbial physiology differently in topsoil and subsoil under a temperate grassland. Geoderma, 336, 22, 2019.

34. ZHANG X., JIANG H., JIN J., XU X., ZHANG Q. Analysis of acid rain patterns in northeastern China using a decision tree method. Atmospheric Environment, 46, 590, 2012.

35. MEE (Ministry of Ecology and Environment, PRC). Report on the state of ecology and environment in China in 2017. Retrieved from http://english.mee.gov.cn/Resources/ Reports/soe/SOEE2017/201808/P020180801597738742758. pdf, 2018

36. VAN BREEMEN N., MULDER J., DRISCOLL C. Acidification and alkalinization of soils. Plant and soil, $\mathbf{7 5}$ (3), 283, 1983.

37. REUSS J.O., JOHNSON D.W. Acid deposition and the acidification of soils and waters (Vol. 59). Springer Science \& Business Media. 2012.

38. GUO J., LIU X., ZHANG Y., SHEN J., HAN W., ZHANG W., CHRISTIE P., GOULDING K.W.T., VITOUSEK P.M., ZHANG F. Significant Acidification in Major Chinese Croplands, 327, 4, 2010.

39. JANOVSKÝ M.P., KARLÍK P., HORÁK J., ŠMEJDA L., ASARE OPARE M., BENEŠ J., HEJCMAN M. Historical land-use in an abandoned mountain village in the Czech Republic is reflected by the $\mathrm{Mg}, \mathrm{P}, \mathrm{K}, \mathrm{Ca}, \mathrm{V}, \mathrm{Cr}, \mathrm{Mn}, \mathrm{Fe}$, $\mathrm{Ni}, \mathrm{Cu}, \mathrm{Zn}, \mathrm{Rb}, \mathrm{Zr}$, and $\mathrm{Sr}$ content in contemporary soils. CATENA, 187, 104347, 2020.

40. KELEPERTZIS E. Accumulation of heavy metals in agricultural soils of Mediterranean: Insights from Argolida basin, Peloponnese, Greece. Geoderma, 221-222, 82, 2014.

41. LASOTA J., BŁOŃSKA E., ŁYSZCZARZ S., TIBBETT M. Forest Humus Type Governs Heavy Metal Accumulation in Specific Organic Matter Fractions. Water, Air, \& Soil Pollution, 231 (2), 80, 2020.

42. MARCHAND C., ALLENBACH M., LALLIER-VERGÈS E. Relationships between heavy metals distribution and organic matter cycling in mangrove sediments (Conception Bay, New Caledonia). Geoderma, 160 (3-4), 444, 2011.

43. ZWOLIŃSKI J. Rates of organic matter decomposition in forests polluted with heavy metals. Ecological Engineering, 3 (1), 17, 1994. 
44. SCHRUMPF M., KAISER K., GUGGENBERGER G., PERSSON T., KÖGEL-KNABNER I., SCHULZE E.D. Storage and stability of organic carbon in soils as related to depth, occlusion within aggregates, and attachment to minerals. Biogeosciences Discussions, 9 (9), 13085, 2012.

45. YU T., FU Y., HOU Q., XIA X., YAN B., YANG Z. Soil organic carbon increase in semi-arid regions of China from 1980s to 2010s. Applied Geochemistry, 116, 104575, 2020.

46. KÖGEL-KNABNER I., GUGGENBERGER G., KLEBER M., KANDELER E., KALBITZ K., SCHEU S., EUSTERHUES K., LEINWEBER P. Organo-mineral associations in temperate soils: Integrating biology, mineralogy, and organic matter chemistry. Journal of Plant Nutrition and Soil Science, 171 (1), 61, 2008.

47. KEILUWEIT M., BOUGOURE J.J., NICO P.S., PETTRIDGE J., WEBER P.K., KLEBER M. Mineral protection of soil carbon counteracted by root exudates. Nature Climate Change, 5 (6), 588, 2015.

48. KOVEN C.D., HUGELIUS G., LAWRENCE D.M., WIEDER W.R. Higher climatological temperature sensitivity of soil carbon in cold than warm climates. Nature Climate Change, 7 (11), 817, 2017.

49. ZHANG L., WANG G., ZHENG Q., LIU Y., YU D., SHI X., XING S., CHEN H., FAN X. Quantifying the impacts of agricultural management and climate change on soil organic carbon changes in the uplands of Eastern China. Soil and Tillage Research, 174, 81, 2017.

50. ZHANG W., WANG X., XU M., HUANG S., LIU H., PENG C. Soil organic carbon dynamics under long-term fertilizations in arable land of northern China, 17, 2010.
51. WIESMEIER M. Amount, distribution and driving factors of soil organic carbon and nitrogen in cropland and grassland soils of southeast Germany (Bavaria), 14, 2013.

52. GUO Y., ZHANG Y., WEI J., GAO B., LI Y., DONG X. Effects of Long- term Chemical Fer tilization on Soil Physical Properties of three soils in Shandong Province (in Chinese). Chinese Agricultural Science Bulletin, 023 (012), 244, 2007.

53. THOMSEN I.K., SCHJØNNING P., JENSEN B., KRISTENSEN K., CHRISTENSEN B.T. Turnover of organic matter in differently textured soils II. Microbial activity as influenced by soil water regimes. Geoderma, 89 (3-4), 199, 1999.

54. LARSEN R.K., BAKER J.E. Source Apportionment of Polycyclic Aromatic Hydrocarbons in the Urban Atmosphere: A Comparison of Three Methods. Environmental Science \& Technology, 37 (9), 1873, 2003.

55. JIA X., YANG Y., ZHANG C., SHAO M., HUANG L. A State- Space Analysis of Soil Organic Carbon in China's Loess Plateau. Land Degradation \& Development, 28 (3), 983, 2017.

56. GŁĄB T., KACORZYK P. Root distribution and herbage production under different management regimes of mountain grassland. Soil and Tillage Research, 113 (2), 99, 2011.

57. CARTER M.R., GREGORICH E.G. Carbon and nitrogen storage by deep-rooted tall fescue (Lolium arundinaceum) in the surface and subsurface soil of a fine sandy loam in eastern Canada. Agriculture, Ecosystems \& Environment, 136 (1), 125, 2010. 